\title{
ANALISIS FAKTOR-FAKTOR YANG MEMPENGARUHI KINERJA KARYAWAN PT. BIO NUSANTARA TEKNOLOGI Jl. Lintas Utara Km. 19 Bengkulu Tengah
}

\author{
Merta Kusuma, Tm. Said \\ Fakultas Ekonomi Universitas Muhammadiyah Bengkulu \\ Kmertaa@yahoo.com
}

\begin{abstract}
ABSTRAK
Merta Kusuma, Tm. Said: Tujuan dari penelitian ini adalah untuk mengetahui pengaruh motivasi, lingkungan kerja, seleksi, dan pelatihan terhadap kinerja karyawan di PT BIO Nusantara Teknologi. Populasi dalam penelitian ini adalah 550 karyawan tetap di PT BIO Nusantara Teknologi. Teknik pengambilan contoh yang digunakan dalam penelitian ini adalah Nonprobability dan Insidental Sampling. Untuk menentukan sampel digunakan rumus Solvin, maka ada 84 orang sebagai sampel. Teknik pengumpulan data adalah kuesioner observasi, dan wawancara. Teknik analisis data yang digunakan oleh peneliti adalah analisis kualitatif dan kuantitatif yang terdiri dari model regresi berganda dan koefisien determinasi.

Hasil penelitian ini menggunakan uji regresi $\mathrm{Y}=6.003+0.230 \mathrm{X} 1+0.134 \mathrm{X} 2+0.188 \mathrm{X} 3+0.232 \mathrm{X} 4$. Sedangkan hasil determinasi $\mathrm{R}=0,472$ dan $\mathrm{R} 2=0223$. Uji t signifikan tingkat $<0,05$ sehingga, ada pengaruh yang signifikan, jika tingkat signifikan> 0,05 sehingga tidak ada pengaruh yang signifikan, hasil dari masing-masing t sig adalah 0,021 untuk variabel motivasi, 0,034 untuk variabel lingkungan kerja, 0,045 untuk seleksi, dan 0,049 untuk variabel pelatihan. Keempat variabel tersebut adalah $<0,05$ sehingga ada pengaruh yang signifikan. Selanjutnya, uji F, jika F sig <0,05 dan (tabel Fanova $>$ F) maka Ho ditolak ad H1 diterima, hasil $\mathrm{F}$ sig $=(0,000)<0,05$ dan $(5,673>2,337)$ jadi, Model regresi dapat digunakan untuk memprediksi variabel kinerja pegawai atau dapat dikatakan bahwa variabel motivasi (X1), lingkungan kerja (X2), seleksi (X3), dan pelatihan (X4) dipengaruhi kinerja karyawan (Y) bersama di PT BIO Nusantara Teknologi.
\end{abstract}

\section{ABSTRACT}

Merta Kusuma, Tm. Said:The purpose of this research is to know the influence of motivation, work environment, selection, and training toward employee's performance in PT BIO Nusantara Teknologi. Population of this research was 550 permanent employees in PT BIO Nusantara Teknologi. Sampling techniques that used in this research were Nonprobability and Insidental sampling. To determined the sample used Solvin formula, so there was 84 people as samples. Data collection techniques were observation questionnaire, and interview. Data analysis techniques used by researcher were qualitative and quantitative analysis which consists of a multiple regression model and coefficient of determination.

The result of this research $u$ sed regression test $Y=6.003+0.230 X_{1}+0.134 X_{2}+0.188 X_{3}+0.232 X_{4}$. While the result of determination $R=0.472$ and $R 2=0223$. T test significant level $<0,05$ so, there was significant influence, if significant level $>0,05$ so, there was not significant influence, the result of each $t$ sig was 0,021 for motivation variable, 0,034 for work environment variable, 0,045 for selection, and 0,049 for training variable. The four variables were $<0,05$ so there was significant influence. Next, $F$ test, if $F$ sig $<0,05$ and (Fanova $>F$ table) so, Ho was rejected ad H1 was accepted, the result of $F$ sig $=(0,000)<0,05$ and $(5,673>2,337)$ so, the regression model can be used to predict employee's performance variable or it can be said that the motivation variable (X1), work environment(X2), selection(X3), and training(X4) were influenced employee's performance(Y) together in PT BIO Nusantara Teknologi.

Key Words: Motivation, Work Environment, Selection, Training and Employee's Performance.

\section{PENDAHULUAN}

Sumber daya manusia merupakan yang terpenting dalam suatu perusahaan dimana karyawan memberikan tenaga, bakat, kreatifitas, dan usaha mereka kepada perusahaan. Oleh karena itu manusia merupakan asset perusahaan yang kinerja karyawan tak hanya dilihat dari kemampuan kerja yang sempurna tetapi dalam menguasai dan mengelola diri sendiri.

Dalam rangka mempertahankan dan mengembangkan usaha, organisasi sering mengalami kendala yang meliputi perubahan informasi, teknologi, dan adanya kebutuhan sumber daya manusia berkompeten serta persaingan usaha yang semakin ketat. Hal ini membuat organisasi harus bertindak antisipatif salah satunya dengan cara beradaptasi terhadap perubahan-perubahan tersebut dan melakukan 
efisiensi serta efektivitas operasional kerja sehingga hasil kerja dapat sesuai dengan tujuan yang ditetapkan. Untuk mendapatkan hasil yang baik, salah satunya harus didukung oleh sumberdaya manusia berkualitas dan memiliki keunggulan kompetitif yaitu multi skilling knowledge yang menjadi kekuatan bagi organisasi untuk menghadapi tantangan usaha.

Manusia merupakan sumber daya terpenting dalam suatu organisasi, karena manusia memiliki peranan yang dominan pada sebagian besar kegiatan operasional seperti merencanakan, mengkoordinasikan, mengatur, menjalankan dan mengawasi praktek kerja.hal itu nantinya akan membantu pencapaian tujuan yang sudah ditentukan organisasi sebelumnya.

Pemimpin perusahaan hendaklah yang memiliki sifat menjunjung tinggi kedisiplinan serta menjadi contoh bagi karyawanya untuk melakukan hal-hal yang bisa meningkatkan kinerja para bawahanya.Menurut Prof. Dr. Suparno Eko Widodo (2015:187) motivasi adalah kekuatan yang ada dalam seseorang, yang mendorong perilakunya untuk melakukan tindakan. Artinya jika prosedur dan metode yang diterapkan oleh organisai sesuai dengan ketentuan yang berlaku, maka karyawan akan merasa betah untuk berkerja, dan sebaliknya jika metode yang dilakukan kurang jelas, maka kecenderungan yang akan timbul adalah buruknya kinerja karyawan, atau bahkan keluarnya karyawan dari organisasi tersebut. Berjalanya kegiatan suatu organisasi secara propesional tersebut tentunya tidak terlepas dari peranan karyawan yang berkerja pada organisasi tersebut. Maka dari itu dibutukan cara untuk meningkatkan kinerja karyawan melalui motivasi yang diberikan.

Lingkungan kerja merupakan elemen-elemen organisasi sebagai sistem sosial yang mempunyai pengaruh yang kuat didalam pembentukan perilaku individu pada organisasi dan berpengaruh terhadap prestasi organisais(Rivai : 2006). Karyawan setiap harinya melakukan komunikasi, menjalankan tugas serta bekerja sama dengan rekan kerjanya, hal ini tentu mempengaruhi semangat yang ada dalam diri individu maupun kelompok, semakin berhubungan baik antara karyawan satu dengan yang lain maka hasil dari kinerja yang dilakukan akan membaik juga. Selanjutnya Hamzah (2002:25) menjelaskan bahwa "sarana dan prasarana kerja yang ada dalam lingkungan organisasi tempat bekerja sebagai faktor pendukung operasional kerja sangatlah diperlukan, hal ini dimaksudkan untuk mempermudah pekerjaan atau gerak aktivitas dalam pengelolaanya, maka diperlukan adanya peralatan yang baik, cukup sesuai kebutuhan efisien dan efektif serta praktis dalam penggunaanya."

Dalam bekerja karyawan tentu memiliki keahlian yang berbeda-beda hal inilah yang harus di perhatikan lebih lanjut tentang penempatan kerja yang sesuai dengan keahlian yang dimiliki karyawan tersebut dengan tujuan dapat menghasilkan kinerja yang optimal. Masalah kinerja bila karyawan tidak punya pengetahuan dan sikap positif, karyawan ini boleh jadi tidak ditempatkan pada posisi atau jabatan yang sesuai. Ini bisa mengisyaratkan adanya masalah dalam seleksi atau promosi karyawan. Berdasarkan itu maka kegiatan seleksi itu mempunyai arti yang sangat strategis dan penting bagi perusahaan. Menurut Mathis dan Jackson (2006 : 261) Seleksi merupakan proses pemilihan orang-orang yang memiliki kualifikasi yang dibutuhkan untuk mengisi lowongan pekerjaan di sebuah organisasi.

Selanjutnyadalam perekrutan karyawan baru tidak jarang karyawan tersebut di temukan memiliki kemampuan dan keahlian tepat sesuai dengan kebutuhan organisasi, hal ini juga terjadi bila ada perubahan teknologi yang diterapkan oleh organisasi dengan ketersediaan kemampuan dan keahlian personel yang ada. Jadi pelatihan di perlukan untuk penyesuaian dan peningkitan kemampuan serta keterampilan yang dimiliki karyawan agar memenuhi kebutuhan organisasi. menurut Kaswan (2013:2) pelatihan adalah proses meningkatkan pengetahuan dan keterampilan karyawan. Pelatihan mungkin juga meliputi pengubahan sikap sehingga karyawan dapat melakukan pekerjaanya lebih efektif.

Kinerja pada dasarnya adalah apa yang dilakukan karyawan sehingga mempengaruhi banyaknya kontribusi yang diberikan kepada perusahaan termasuk pelayanan yang berkualitas yang disajikan. Kesuksesan dari perusahaan bisa dilihat dari pekerjaan yang telah dicapai oleh karyawannya, oleh sebab itu perusahaan menuntut agar para karyawannya mampu menampilkan kinerja yang optimal. Untuk itu kinerja dari para karyawan harus mendapat perhatian dari para pimpinan perusahaan, sebab menurunnya kinerja dari karyawan dapat mempengaruhi kinerja perusahaan secara keseluruhan.

Di dalam suatu perusahaan, karyawan harus mempunyai kecerdasan intelektual dan kecerdasan emosional untuk meningkatkan kinerja karyawan. Intelektual merupakan kumpulan sistematis dari kemampuan untuk berpikir dan bertindak secara terarah serta mengolah informasi secara efektif, untuk mencapai tujuan tertentu. Tetapi, saat ini kinerja seorang karyawan bukan hanya ditunjang oleh kemampuan intelektual namun juga didukung oleh kemampuan pengendalian emosi dalam berhubungan dengan seseorang. Masyarakat beranggapan bahwa semakin tinggi IQ (Intelligence Quotient) seseorang semakin berhasil orang tersebut dalam pekerjaan. 


\section{Kinerja}

Menurut pendapat Vroom dalam Luthans (2006 : 279) kinerja ialah tingkat sejauh mana keberhasilan seseorang dalam menyelesaikan pekerjaannya disebut "Level of Performance", bila karyawan yang memiliki Level of Performance tinggi maka dapat dikategorikan sebagai karyawan produktif dan sebaliknya jika ada karyawan yang Level of Performancenya rendah maka dapat dikatakan sebagai karyawan yang sudah tidak produktif.

Kinerja seseorang merupakan kombinasi dari kemampuan, usaha, dan kesempatan yang dapat dinilai dari hasil kerjanya menurut pendapat Sulistiyani (2003:223). Bernardin dan Russel dalam Sulistiyani (2003:223) menyatakan bahwa kinerja merupakan catatan outcome yang dihasilkan dari fungsi pegawai tertentu atau kegiatan yang dilakukan selama periode waktu tertentu. Sedangkan menurut Mathis dan Jackson dalam Ahmad Subekhi (2012:193) kinerja pada dasarnya adalah apa yang dilakukan atau tidak dilakukan karyawan.Menurut Maluyu S.P. Hasibuanmengemukakan "kinerja adalah suatu hasil kerja yang dicapai seseorang dalam melaksanakan tugas-tugas yang dibebankan kepadanya yang didasarkan atas kecakapan, pengalaman, kesungguhan serta waktu".

Kinerja mengacu pada prestasi karyawan yang diukur berdasarkan standar atau kriteria yang ditetapkan perusahan. Pengertian kinerja atau prestasi kerja diberi batasan oleh Maier (dalam Moh As'ad, 2003) sebagai kesuksesan seseorang di dalam melaksanakan suatu pekerjaan.

\section{Indikator Kinerja}

Mmenurut Mathis dan Jackson dalam Ahmad Subekhi (2012:193) bahwa kinerja meliputi beberapa indikator kinerja yaitu:

1. Kuantitas dari hasil

2. Kualitas dari hasil

3. Ketepatan waktu dari hasil

4. Kehadiran

5. Kemampuan untuk bekerja sama

\section{Motivasi}

Motivasi adalah kekuatan yang ada dalam seseorang, yang mendorong perilakunya untuk melakukan tindakan. Menurut Suparno Eko Widodo (2015 : 187) Besarnya intensitas kekuatan dari dalam diri seseorang untuk melakukan suatu tugas atau mencapai sasaran memperlihatkan sejauh mana tingkat motivasinya. Motivasi adalah masalah yang kompleks. Tidak ada seperangkat petunjuk yang mudah dan dapat menjamin membangkitkan dan meningkatkan motivasi seseorang. Upaya meningkatkan dan mempertahankan motivasi memerlukan perjuangan tanpa henti bagi para pimpinan dan anggotanya.

Menurut Terry G (1986) dalam Soekidjo Notoatmodjo (2009 : 114) Motivasi adalah keinginan yang terdapat pada diri seseorang individu yang mendorongnya untuk melakukan perbuatan-perbuatan (perilaku).

Menurut Stooner (1992) dalam Soekidjo Notoatmodjo (2009 : 115) mendefinisikan bahwa motivasi adalah sesuatu hal yang menyebabkan dan yang mendukung tindakan atau perilaku seseorang.

\section{Lingkungan Kerja}

Menurut Rivai (2006 : 144) Lingkungan kerja merupakan elemen-elemen organisasi sebagai sistem sosial yang mempunyai pengaruh yang kuat di dalam pembentukan perilaku individu pada perusahaan dan berpengaruh pada prestasi perusahaan.

Selanjutnya Hamzah (2002:25) menjelaskan bahwa sarana dan prasarana kerja yang ada dalam lingkungan organisasi tempat bekerja sebagai faktor pendukung operasional kerja sangatlah diperlukan, hal ini dimaksudkan untuk mempermudah pekerjaan atau gerak aktivitas dalam pengelolaannya, maka diperlukan adanya peralatan yang baik, cukup sesuai kebutuhan, efisien dan efektif serta praktis dalam penggunaannya.

Menurut Nitisemito (2000 : 109) Lingkungan Kerja adalah segala sesuatu yang ada disekitar para pekerja yang dapat mempengaruhi dirinya dalam menjalankan tugas-tugas yang dibebankan padanya.

Menurut sukanto (2000 : 114) lingkungan kerja adalah sesuatu yang ada disekitar karyawan yang dapat mempengaruhi dalam bekerja, meliputi pengaturan penerangan, pengontrolan suara gaduh, pengaturan kebersihan tempat kerja dan pengaturan keamanan tempat kerja.

\section{Seleksi}

Seleksi (selection) menurut Mathis dan Jackson dalam Akhmad Subekti, M.M (2012 : 137) adalah proses pemilihan orang-orang yang memiliki kualifikasi yang dibutuhkan untuk mengisi lowongan pekerjaan di sebuah organisasi. 
Menurut M.T.E Hariandja dalam Akhmad Subekhi, M.M (2012 : 140) seleksi merupakan proses untuk memutuskan pegawai yang tepat dari sekumpulan calon pegawai yang didapat melalui proses perekrutan, baik perekrutan internal maupun eksternal. Proses ini seperti halnya rekrutmen, merupakan kegatan yang sangat penting sebab hasil yang didapat dari perekrutan tidak menjamin semua calon yang direkrut sesuai dengan perusahaan.

Menurut Marwansyah (2009 : 128) seleksi adalah proses identifikasi dan pemilihan orang-orang dari sekelompok pelamar yang paling cocok atau yang paling memenuhi syarat untuk jabatan atau posisi tertentu.

Menurut Veithzal Rivai dalam Akhmad Subekhi (2012 : 138) seleksi adalah kegiatan dalam manajemen SDM yang dilakukan setelah proses rekrutmen seleksi dilaksanakan.

\section{Pelatihan}

Edwin B. Flippo dalam Mohammad Jauhar, S.P.d (2012: 68) menggunakan istilah pelatihan untuk pegawai pelaksana. Pelatihan adalah istilah yang mengarah pada usaha yang terencana yang dirancang untuk memfasilitasi kebutuhan keterampilan, pengetahuan dan sikap yang sesuai dengan perusahaan.

Menurut Gary Dessler dalam Akhmd Subekhi (2012: 70) mendefinisikan pelatihan sebagai proses mengajarkan karyawan baru atau yang ada sekarang, keterampilan dasar yang mereka butuhkan untuk menjalankan pekerjaan mereka.

Mathis dan Jackson dalam Akhmad Subekhi (2012: 70) pelatihan adalah memberikan karyawan pengetahuan dan keterampilan yang spesifik dan dapat diidentifikasi untuk digunakan dalam pekerjaan mereka saat ini.

Hadari Nawawi dalam Akhmad Subekhi (2012: 70) pelatihan adalah program-program untuk memperbaiki kemampuan melaksanakan pekerjaan secara individual, kelompok berdasarkan jenjang jabatan dalam organisasi/perusahaan.

\section{Pengaruh Motivasi Terhadap Kinerja}

Kreitner, dkk (2006) menjelaskan untuk dapat mencapai kinerja yang baik tergantung pada dua faktor yaitu kemempuan (ability), dan motivasi (motivation). Kedua faktor ini saling bergantung untuk mendapatkan kinerja yang baik. Menurut Handoko (2007) faktor yang mempengaruhi kinerja seorang individu yaitu motivasi, kemempuan, dan presepsi peranan. Motivasi, kemampuan dan presepsi peranan adalah sangat berhubungan. Apabila salah satu faktor tersebut rendah, maka tingkat prestasi atau kinerja karyawan juga akan rendah walaupun faktor lainya tinggi.

Selanjutnya Mursi (2008) menjelaskan bahwa kinerja karyawan dipengaruhi oleh motivasi, pengalaman, keterampilan, dan kemempuan.

\section{Pengaruh Lingkungan Kerja Terhadap Kinerja}

Menurut Artoyo (1996 : 23) mengemukakan bahwa lingkungan kerja mempunyai pengaruh terhadap kinerja karyawan. Kinerja dipengaruhi oleh fasilitas kerja, cahaya, udara dan lain-lain, yang kesemuanya itu termasuk dalam lingkungan kerja. Lingkungan kerja yang kurang mendukung dalam pelaksanaan pekerjaan, ikut menyebabkan kinerja yang buruk seperti kurangnya alat kerja, ruang kerja yang pengap, ventilasi yang kurang dan prosedur yang tidak jelas.

Dari pendapat diatas dapat diketahui bahwa ini termasuk dalam lingkungan kerja yaitu kondisi kerja. Sedangkan pelayanan karyawan merupakan fasilitas yang diberikan perusahaan kepada karyawan, dan hubungan karyawan merupakan hubungan antara karyawan dan pimpinan serta hubungan antar rekan kerja. Dari uraian diatas dapat disimpulkan bahwa lingkungan kerja organisasi mempunyai hubungan dengan kinerja mereka. Lingkungan kerja yang baik akan memotivasi karyawan untuk bekerja lebih baik sehingga kinerja dapat ditingkatkan, sebaiknya lingkungan kerja yang buruk dapat menurunkan kinerja karyawan.

\section{Pengaruh Seleksi Terhadap Kinerja}

Menurut Veithzal Rivai (2008 : 170) seleksi adalah kegiatan dalam manajemen SDM yang dilakukan setelah proses rekrutmen seleksi dilaksanakan. Hal ini berarti telah berkumpul sejumlah pelamar yang memenuhi syarat untuk kemudian dipilih mana yang dapat ditetapkan sebagai karyawan dalam suatu perusahaan. Proses pemilihan ini yang dinamakan seleksi. Berdasarkan itu maka kegiatan seleksi itu mempunyai arti yang sangat strategis dan penting bagi perusahaan. Apabila dilaksanakan sesuai dengan prinsip-prinsip manajemen SDM secara wajar, maka proses seleksi akan dapat menghasilkan pilihan karyawan yang dapat diharapkan kelak memberikan kontribusi yang positif dan baik. Oleh karena itu, seleksi merupakan kegiatan yang benar-benar harus disiapkan secara baik melalui proses yang panjang dan karyawan tersebut dapat bekerja dengan motivasi yang tinggi serta berkarya secara maksimal. 
Seleksi dilaksanakan tidak saja untuk penerimaan karyawan baru saja, akan tetapi seleksi ini dapat pula dilakukan karena untuk mengembangkan, atau penerimaan karena adanya peluang jabatan. Untuk memperoleh atau mendapatkan peluang jabatan tersebut perlu dilakukan seleksi, sehingga dapat diperoleh SDM yang berkualitas sesuai dengan kebutuhan.

Di samping itu, menurut M. T. E. Hariandja (2002 : 125) seleksi juga tidak hanya memilih pegawai yang tepat dilihat dari sudut pandang organisasi. Tetapi juga dari sudut pegawai yang memilih organisasi yang sesuai dengan keinginannya. Hal ini penting sebab unjuk kerja seseorang tidak hanya dipengaruhi oleh kemampuan yang dimiliki, tetapi juga oleh sikapnya terhadap organisasi, dalam pengrtian keyakinannya bahwa organisasi yang dimasuki akan dapat mewujudkan harapan-harapan yang mengakibatkan dia senang bekerja di organisasi tersebut.

\section{Pengaruh Pelatihan Terhadap Kinerja}

MenurutHendri Simamora (2001 : 71) mengemukakan dengan adanya peningkatan keahlian pengetahuan dan wawasan, sikap personil pada tugasnya diharapkan dengan pengetahuan yang didapat dalam pelatihan akan merubah tingkah laku, guna mendapatkan produktivitas yang tinggi.

Pemberian pelatihan dapat meningkatkan kinerja, karena kinerja perusahaan tidak akan tercapai bila karyawan tidak meningkatkan pengetahuan, keterampilan baik secara teknis maupun manajerial, sehingga karyawan dapat lebih mudah melakukan tugas-tugas yang menjadi tanggung jawabnya. Peningkatan kemampuan harus sesuai dengan perkembangan ilmu pengetahuan dan teknologi, dan pelatihan yang dilakukan bersifat terpadu.

Dengan demikian pelatihan merupakan modal utama pada suatu organisasi/instansi untuk meraih keberhasilan dan kesuksesan dalam mencapai tujuan perusahaan karena sumber daya manusia yang diinginkan oleh suatu organisasi adalah sumber daya yang berkualitas dan sumber daya manusia yang berkualitas akan mencapai kinerja yang optimal.

\section{Kerangka Analisis}

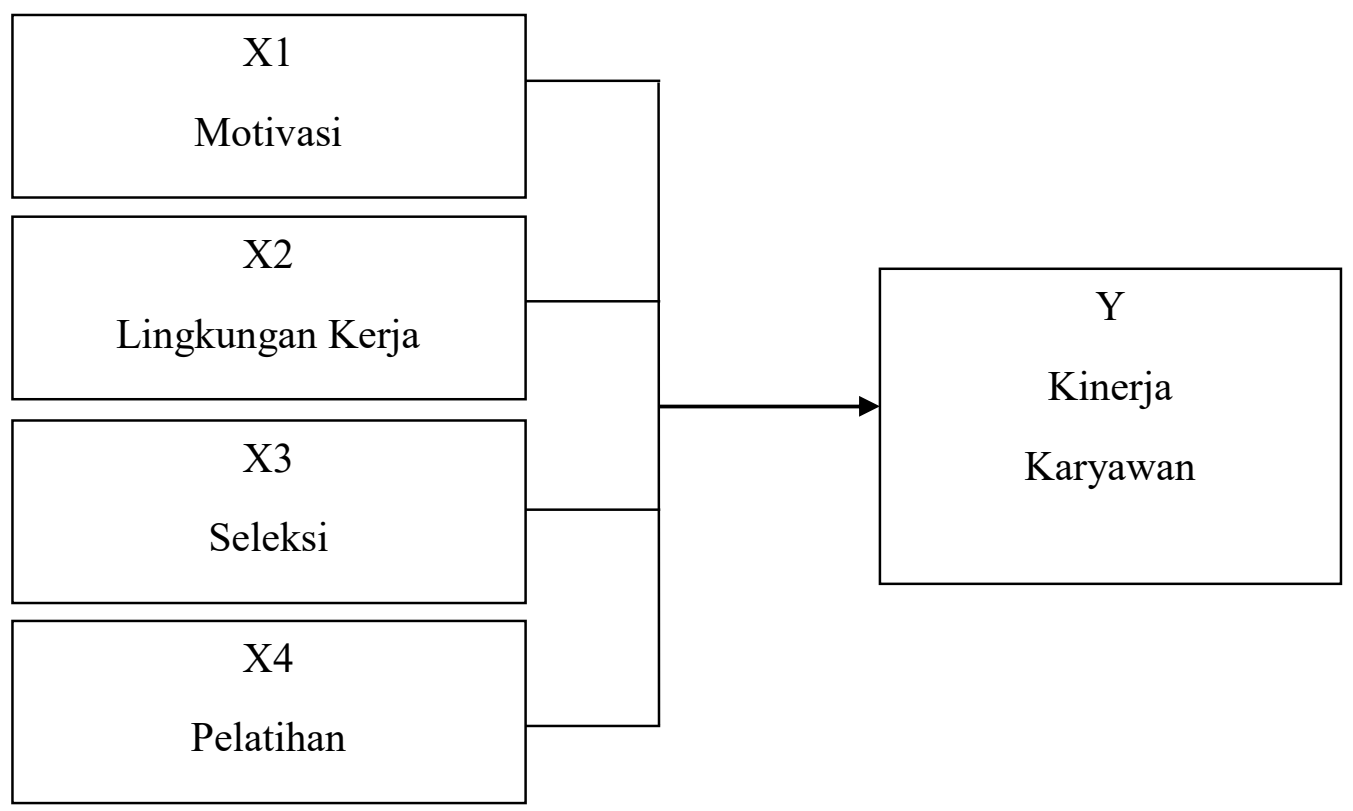

Gambar 1. Kerangka analisis

Sumber yang digunakan untuk bahan acuan dalam penelitian ini adalah Motivasi (Mangkuegara, 2011), Lingkungan Kerja (P. Siagian, 2004), Seleksi (Simamora, 2004), Pelatihan (Benardin dan Russel dalam Mus Hudi, 2000), dan Kinerja (Mathis dan Jackson dalam Ahmad Subekhi, 2012)

\section{METODE PENELITIAN}

Dalam penelitan ini, penulis menggunakan penelitan survey yaitu penelitian yang mengambil sampel dari populasi dan menggunakan kuesioner sebagai alat dalam pengumpulan data, (Sugiyono, 2012). Data yang diperoleh kemudian diolah, dianalisis, dibahas dan diuraikan secara sistematis sehingga 
diperoleh kesimpulan. Objek dalam penelitian ini adalah karyawan yang bekerja di PT. BIO Nusantara Teknologi. Pada Penelitian ini populasi sampel yang digunakan sebanyak 84 orang

\section{Metode Pegumpulan Data}

Metode pengumpulan data yang paling pokok dilakukan dalam penelitian ini adalah:

1. Observasi, sebagai teknik pengumpulan data mempunyai ciri yang spesifik, observasi tidak terbatas pada orang, tetapi juga pada obyek-obyek alam yang lain yang ada di PT. BIO Nusantara Teknologi Bengkulu Tengah.

2. Kuesioner, yaitu teknik pengumpulan data dengan cara menyebarkan angket yang berisi daftar pertanyaan yang harus diisi oleh para reponden. Informasi atau data yang diperoleh dari jawaban kuesioner ini dijadikan sebagai sumber informasi utama untuk melakukan analisis hasil penelitian.

3. Wawancara dengan pihak terkait baik dari pimpinan maupun karyawan itu sendiri untuk memperoleh informasi atau data yang ditanyakan secara langsung dan dijadikan sebagai sumber informasi sebagai pendukung dalam melakukan analisis hasil penelitian.

\section{Teknik Analisis Data}

Metode analisis data yang digunakan/dipakai peneliti dalam penelitian ini adalah:

1. Analisis Kualititaif yang menjelaskan (mendeskripsikan) pengaruh Motivasi $\left(\mathrm{X}_{1}\right)$, Lingkungan Kerja $\left(\mathrm{X}_{2}\right)$, Seleksi $\left(\mathrm{X}_{3}\right)$ dan Pelatihan $\left(\mathrm{X}_{4}\right)$ terhadap Kinerja ( $\left.\mathrm{Y}\right)$.

2. Analisis kuantitatif yaitu anaslisis dengan pengolahan data menggunakan alat ststistik antara lain

a. Model Regresi Berganda

Model Regresi Berganda yang digunakan adalah untuk menghitung besarnya pengaruh Motivasi $\left(\mathrm{X}_{1}\right)$, Lingkungan Kerja $\left(\mathrm{X}_{2}\right)$, Seleksi $\left(\mathrm{X}_{3}\right)$ dan Pelatihan $\left(\mathrm{X}_{4}\right)$ terhadap Kinerja $(\mathrm{Y})$. Maka digunakan alat analisis regeresi linier berganda dengan rumus sebagai berikut :

\begin{tabular}{lll} 
& $\mathbf{Y}=\mathbf{a}+\mathbf{b}_{\mathbf{1}} \mathbf{X}_{\mathbf{1}}+\mathbf{b}_{\mathbf{2}} \mathbf{X}_{\mathbf{2}}+\mathbf{b}_{\mathbf{3}} \mathbf{X}_{\mathbf{3}}+\mathbf{b}_{\mathbf{4}} \mathbf{X}_{\mathbf{4}} \quad$ (Sugiyo \\
Keterangan: & \multicolumn{2}{l}{ Skor kinerja karyawan } \\
$\mathrm{Y}$ & \multicolumn{2}{l}{ Konstanta atau bila $\mathrm{x}=0$} \\
$\mathrm{a}$ & $:$ & Koefisien regresi \\
$\mathrm{b}_{1}, \mathrm{~b}_{2}, \mathrm{~b}_{3}, \mathrm{~b}_{4}$ & $:$ & Skor variabel Motivasi \\
$\mathrm{X}_{1}$ & $:$ & Skor variabel Lingkungan Kerja \\
$\mathrm{X}_{2}$ & $:$ & Skor variabel Seleksi \\
$\mathrm{X}_{3}$ & $:$ & Skor variabel Pelatihan \\
$\mathrm{X}_{4}$ &
\end{tabular}

\section{HASIL DAN PEMBAHASAN}

\section{Tanggapan Responden Terhadap Variabel Motivasi}

Berdasarkan hasil penelitian dapat diketahui rata-rata jawaban responden untuk variabel motivasi (X1) sebesar 3,61. Nilai ini menunjukan tanggapan responden atas variabel motivasi (X1) berada pada kriteria baik karena terletak pada interval penilaian antara 3,40 - 4,19. Dapat disimpulkan bahwa karyawan PT. BIO Nusantara Teknologi membutuhkan motivasi baik dari atasan maupun rekan kerja agar dapat melaksanakan kinerja dengan baik, serta memiliki harapan untuk berprestasi sehingga para karyawan memiliki semangat dalam bekerja dan hal ini nantinya diyakini akan menunjang untuk kemajuan perusahaan PT. BIO Nusantara Teknologi kedepanya.

\section{Tanggapan Responden Terhadap Variabel Lingkungan Kerja}

Berdasarkan hasil penelitian dapat diketahui rata-rata jawaban responden untuk variabel lingkungan kerja (X2) sebesar 3,46. Nilai ini menunjukan tanggapan responden atas variabel lingkungan kerja (X2) berada pada kriteria baik karena terletak pada interval penilaian antara 3,40 - 4,19. Dapat disimpulkan bahwa karyawan PT. BIO Nusantara Teknologi memiliki lingkungan kerja yang bagus dapat dilihat dari fasilitas serta sarana dan prasarana yang diberikan oleh pihak perusahan cukup memadai dalam rangka untuk menunjang kegiatan bekerja yang akan dilakukan karyawan, serta hubungan antara atasan dengan bawahan dan karyawan dengan karyawan berjalan cukup harmonis sehingga dalam bekerja mereka tidak terasa terebani, dan hal ini nantinya diyakini akan menunjang untuk kemajuan perusahaan PT. BIO Nusantara Teknologi kedepanya.

\section{Tanggapan Responden Terhadap Variabel Seleksi}

Berdasarkan Hasil penelitian dapat diketahui rata-rata jawaban responden untuk variabel seleksi (X3) sebesar 3,87. Nilai ini menunjukan tanggapan responden atas variabel seleksi (X3) berada pada 
kriteria baik karena terletak pada interval penilaian antara 3,40 - 4,19. Dapat disimpulkan bahwa karyawan PT. BIO Nusantara Teknologi telah menerapkan kegiatan seleksi yang baik serta penempatan dari karyawan sesuai dengan keahlian yang dimiliki sehingga dalam bekerja karyawan akan sangat mengerti dalam melaksanakan tugasnya masing-masing, hal ini nantinya diyakini akan menunjang untuk kemajuan perusahaan PT. BIO Nusantara Teknologi kedepanya.

\section{Tanggapan Responden Terhadap Variabel Pelatihan}

Berdasarkan hasil penelitian dapat diketahui rata-rata jawaban responden untuk variabel pelatihan (X4) sebesar 3,63. Nilai ini menunjukan tanggapan responden atas variabel pelatihan (X4) berada pada kriteria baik karena terletak pada interval penilaian antara 3,40 - 4,19. Dapat disimpulkan bahwa karyawan PT. BIO Nusantara Teknologi telah diberikan pelatihan yang cukup baik seperti penambahan pengetahua, penambahan keterampilan dan penambahan kemampuan yang rutin diberikan setiap setahun sekali, serta untuk karyawan yang baru direkrut akan dilakukan training terlebih dahulu agar dapat bekerja sebagai yang diharapkan. Hal ini nantinya diyakini akan menunjang untuk kemajuan perusahaan PT. BIO Nusantara Teknologi kedepanya.

\section{Tanggapan Responden Terhadap Variabel Kinerja Karyawan}

Berdasarkan hasil penelitian dapat diketahui rata-rata jawaban responden untuk variabel kinerja karyawan (Y) sebesar 3,61. Nilai ini menunjukan tanggapan responden atas variabel kinerja karyawan (Y) berada pada kriteria baik karena terletak pada interval penilaian antara 3,40 - 4,19. Dapat disimpulkan bahwa kinerja karyawan PT. BIO Nusantara Teknologi dalam penelitian ini dalam kategori baik. Hal ini disebabkan karena adanya motivasi-motivasi yang selalu diberikan kepada karyawan, lingkungan kerja yang baik, pelatihan-pelatihan, seleksi dalam memilih karyawan, serta inovasi yang selalu dilakukan untuk memecahkan kejenuhan dalam bekerja supaya menghasilkan kinerja karyawan yang baik dan hal ini nantinya diyakini akan menunjang untuk kemajuan perusahaan PT. BIO Nusantara Teknologi kedepanya.

\section{Hasil Analisa Regresi.}

Analisa regresi yang dilakukan pada penelitian ini menggunakan metode Enter. Regresi dengan metode enter adalah salah satu metode dalam analisa regresi dengan memasukkan seluruh variabel kedalam suatu model persamaan regresi. Model tersebut dapat dilihat pada output SPSS sebagai berikut:

Tabel 1. Hasil Uji Analisa Regresi Berganda

\begin{tabular}{|c|c|c|c|c|c|c|}
\hline \multicolumn{7}{|c|}{ Coefficients $^{a}$} \\
\hline \multirow{2}{*}{\multicolumn{2}{|c|}{ Model }} & \multicolumn{2}{|c|}{ Unstandardized Coefficients } & \multirow{2}{*}{$\begin{array}{c}\begin{array}{c}\text { Standardized } \\
\text { Coefficients }\end{array} \\
\text { Beta }\end{array}$} & \multirow[t]{2}{*}{$\mathrm{t}$} & \multirow[t]{2}{*}{ Sig. } \\
\hline & & B & Std. Error & & & \\
\hline \multirow{5}{*}{1} & (Constant) & 6.003 & 2.616 & & 2.295 & .024 \\
\hline & Motivasi_X1 & .230 & .098 & .237 & 2.350 & .021 \\
\hline & LingKerja_X2 & .134 & .062 & .215 & 2.153 & .034 \\
\hline & Seleksi_X3 & .188 & .092 & .203 & 2.041 & .045 \\
\hline & Pelatihan_X4 & .232 & .116 & .203 & 2.004 & .049 \\
\hline
\end{tabular}

a. Dependent Variable: Kinerja_Y

Dari kolom B pada unstandardized coefficiets didapatkan persamaan regresi sebagai berikut :

$$
\mathrm{Y}=6.003+0.230 \mathrm{X}_{1}+0.134 \mathrm{X}_{2}+0.188 \mathrm{X}_{3}+0.232 \mathrm{X}_{4}
$$

Dimana :

$\mathrm{Y}=$ Kinerja karyawan

$\mathrm{X}_{1}=$ Motivasi

$$
\begin{aligned}
& \mathrm{X}_{2}=\text { Lingkungan kerja } \quad \mathrm{X}_{4}=\text { Pelatihan } \\
& \mathrm{X}_{3}=\text { Seleksi }
\end{aligned}
$$

Dengan melihat tabel diatas maka dapat dijelaskan sebagai berikut:

1. Nilai konstanta sebesar 6,003dapat diartikan bahwa jika tidak ada variabel motivasi $\left(X_{1}\right)$, lingkungan kerja $\left(\mathrm{X}_{2}\right)$, seleksi $\left(\mathrm{X}_{3}\right)$ dan pelatihan $\left(\mathrm{X}_{4}\right)$ maka kinerja karyawan $(\mathrm{Y})$ sebesar 6,003

2. Nilai koefisien regresi yang berhubungan dengan variabel motivasi $\left(X_{1}\right), 0,230$ dapat diartikan bahwa apabila variabel motivasi meningkat sebesar 1 satuan maka kinerja karyawan (Y) akan naik 
sebesar 0,230 satuan atau $23,0 \%$ dengan asumsi nilai variabel lingkungan kerja $\left(\mathrm{X}_{2}\right)$, seleksi $\left(\mathrm{X}_{3}\right)$ dan pelatihan $\left(\mathrm{X}_{4}\right)$ sama dengan 0 .

3. Nilai koefisien regresi yang berhubungan dengan variabel lingkungan kerja $\left(\mathrm{X}_{2}\right), 0,134$ dapat diartikan bahwa apabila variabel lingkungan kerja meningkat sebesar 1 satuan maka kinerja karyawan (Y) akan naik sebesar 0,134satuan atau 13,4 \% dengan asumsi nilai variabel motivasi $\left(\mathrm{X}_{1}\right)$, seleksi $\left(\mathrm{X}_{3}\right)$ dan pelatihan $\left(\mathrm{X}_{4}\right)$ sama dengan 0 .

4. Nilai koefisien regresi yang berhubungan dengan variabel seleksi $\left(\mathrm{X}_{3}\right), 0,188 \mathrm{dapat}$ diartikan bahwa apabila variabel seleksi meningkat sebesar 1 satuan maka kinerja karyawan $(\mathrm{Y})$ akan naik sebesar 0,188 satuan atau $18,8 \%$ dengan asumsi nilai variabel motivasi $\left(\mathrm{X}_{1}\right)$, lingkungan kerja $\left(\mathrm{X}_{2}\right)$ dan pelatihan $\left(\mathrm{X}_{4}\right)$ sama dengan 0 .

5. Nilai koefisien regresi yang berhubungan dengan variabel pelatihan $\left(\mathrm{X}_{4}\right), 0,232$ dapat diartikan bahwa apabila variabel pelatihan meningkat sebesar 1 satuan maka kinerja karyawan (Y) akan naik sebesar 0,232 satuan atau $23,2 \%$ dengan asumsi nilai variabel motivasi $\left(\mathrm{X}_{1}\right)$, lingkungan kerja $\left(\mathrm{X}_{2}\right)$ dan seleksi $\left(\mathrm{X}_{3}\right)$ sama dengan 0 .

\section{KESIMPULAN}

1. Dari hasil uji regresi liner berganda didapat persamaan regresinya $Y=6.003+0.230 X_{1}+0.134 X_{2}+$ $0.188 \mathrm{X}_{3}+0.232 \mathrm{X}_{4}$ persamaan ini dapat dijelaskan adanya pengaruh positif $(+)$ dari ke empat variabel bebas diantaranya Motivasi $\left(\mathrm{X}_{1}\right)$, Lingkungan Kerja $\left(\mathrm{X}_{2}\right)$, Seleksi $\left(\mathrm{X}_{3}\right)$ dan Pelatihan $\left(\mathrm{X}_{4}\right)$. Yaitu variabel bebas mengalami peningkatan maka akan diikuti peningkatan variabel terikat.

2. Berdasarkan uji koefisien determinasi didapat nilai $\mathrm{R}=0.472(47,2 \%)$ dan koefisien determinasi sebesar $\mathrm{R}^{2}=0.223(22,3 \%)$ nilai ini mempunyai makna bahwa Motivasi $\left(\mathrm{X}_{1}\right)$, Lingkungan Kerja $\left(\mathrm{X}_{2}\right)$, Seleksi $\left(\mathrm{X}_{3}\right)$ dan Pelatihan $\left(\mathrm{X}_{4}\right)$ memiliki pengaruh sebesar 22,3\% terhadap Kinerja karyawan ( $\mathrm{Y}$ ) pada PT. BIO NUSANTARA TEKNOLOGI Jl. Lintas Utara KM. 19 Bengkulu Tengah sedangkan sisanya sebesar $77,7 \%$ dipengaruh oleh variabel-variabel lain yang tidak termasuk dalam penelitian ini.

3. Berdasarkan uji parsial Motivasi $\left(\mathrm{X}_{1}\right) \mathrm{t}_{\mathrm{sig}}<\alpha(0.021<0.05)$, Lingkungan Kerja $\left(\mathrm{X}_{2}\right) \mathrm{t}_{\mathrm{sig}}<\alpha(0.034<0.05)$, Seleksi $\left(\mathrm{X}_{3}\right) \mathrm{t}_{\mathrm{sig}}<\alpha(0.045<0.05)$ dan Pelatihan $\left(\mathrm{X}_{4}\right) \mathrm{t}_{\mathrm{sig}}<\alpha(0.049<0.05)$, memberikan sumbangan dalam mempengaruhi Kinerja karyawan (Y). pada PT. BIO NUSANTARA TEKNOLOGI Jl. Lintas Utara KM. 19 Bengkulu Tengah. Hasil uji hipotesis dengan F-tes diketahui Motivasi ( $\mathrm{X}_{1}$ ), Lingkungan Kerja $\left(\mathrm{X}_{2}\right)$, Seleksi $\left(\mathrm{X}_{3}\right)$ dan Pelatihan $\left(\mathrm{X}_{4}\right)$, memiliki pengaruh secara simultan terhadap Kinerja Karyawan (Y) yaitu $\mathrm{f}_{\text {sig }}<\alpha(0.000<0.05)$

\section{Saran}

1. Pelaksanaan Motivasi oleh pimpinan yang selama ini diberikan harus lebih ditingkatkan lagi, selain itu pimpinan juga harus menaruh perhatian yang serius pada perilaku karyawan pada semua permasalahan kebutuhan baik dengan memberikan bantuan fasilitas kepada karyawan yang akan mendukung kelancaran pelaksanaan pekerjaan.

2. Mengingat lingkungan kerja sebaiknya ditingkatkan lagi seperti melakukan perbaikan terhadap gedung, fasilitas kerja, dan alat-alat keselamatan kerja sehingga karyawan dapat bekerja dengan tenang dan nyaman.

3. Seleksi yang dilakukan oleh perusahaan perlu di perketat lagi karena sumber daya manusia yang terseleksi tersebut adalah orang yang mampu memenuhi kebutuhan kerja dan dapat bekerja diperusahaan.

4. Pelatihan yang diberikan perusahaan harus lebih ditingkatkan dan berkesinambungan terutama pada bagian HRD (Human Resources Development). Pelatihan tersebut bisa berupa pengoperasian komputer (Microsoft Office), selain itu pelatihan yang diberikan juga harus tetap disesuaikan dengan tuntutan pekerjaan yang akan diemban oleh seorang karyawan. Bagi karyawan lama, pelatihan juga tetap harus diberikan untuk lebih mencegah menurunya produktivitas.

\section{DAFTAR PUSTAKA}

Handoko, T. Hani. Dr. “Manajemen Personalia \& Sumber Daya Manusia”. Yogyakarta : BPFE-Yogyakarta. Hasibuan, Melayu S.P. 2005. "Manajemen Sumber Daya Manusia”. Jakarta: PT. Bumi Askara. Marwansyah. (2014). "Manajemen Sumber Daya Manusia”. Bandung : Penerbit Alfabeta.

Novian, (2011). "Pengaruh kompensasi dan lingkungan kerja terhadap kepuasan kerja karyawan pada pt. Mitra ternak sejahtera bengkulu". Skripsi. (Tidak dipublikasikan). Bengkulu : Universitas Muhammadiyah Bengkulu. 
Notoatmodjo, soekidjo. (2009). "Pengembangan Sumber Daya Manusia”. Jakarta : Penerbit Rineka Cipta. P. Siagian, Prof. Dr. Sondang. 2011. "MPA : "Manajemen Sumber Daya Manusia”. Jakarta : PT. Bumi Askara. Sedarmayanti, (2007). "Manajemen Sumber Daya Manusia Reformasi Birokrasi Dan Manajemen Pegawai Negeri Sipil". Bandung: Penerbit PT Refika Aditama.

Subekhi, Akhmad, Jauhar, Mohammad. (2012). "Pengantar Manajemen Sumber Daya Manusia". Jakarta : Penerbit Prestasi Pustakarya.

Sugiyono, Prof. Dr. 2012. "Metode Penelitian Kuantitatif Kualitatif R\&D”. Bandung : Penerbit Alfabeta.

Widodo, suparno eko. (2015). "Manajemen Pengembangan Sumber Daya Manusia”. Yogyakarta : Penerbit Pustaka Pelajar.

http://elib.unikom.ac.id/files/disk1/595/jbptunikompp-gdl-tianurhait-29724-9-unikom t-i.pdf (Di akses 4 April 2016)

http://ejournal.stiesia.ac.id/index.php/jirm/article/viewFile/446/428 (Di akses 23 Mei 2016)

http://repository.usu.ac.id/handle/123456789/22417 (Di akses 23 Mei 2016) 